\title{
The impact of a peer-tutoring program to improve self-regulated learning
}

\author{
Francisco Fernández-Martín*, José L. Arco-Tirado, and Mirian Hervás-Torres
}

Department of Developmental and Educational Psychology, University of Granada (Spain)

\begin{abstract}
Título: Impacto de un programa de tutoría entre iguales para mejorar la autorregulación del aprendizaje.

Resumen: El objetivo de este estudio fue demostrar el impacto de un programa de intervención basado en la tutoría entre iguales para mejorar la autorregulación del aprendizaje del alumnado universitario de nuevo ingreso, identificando asimismo sus efectos en el alumnado tutor. La muestra estuvo compuesta por 102 estudiantes de nuevo ingreso (51 grupo experimental y 51 grupo control) y 50 estudiantes de último curso de cuatro titulaciones. La autorregulación del aprendizaje se evaluó a través del Cuestionario de Estrategias de Aprendizaje y Motivación. Después de asignar aleatoriamente al alumnado de nuevo ingreso a la condición experimental o contro de un diseño cuasiexperimental con grupo control no equivalente mejorado con técnicas de control estadístico, la intervención consistió en 20 sesiones individuales de tutoría altamente estructuradas con el alumnado de nuevo ingreso, dirigidas por el alumnado de último curso o tutor, que fue previamente entrenado para ello en tres sesiones de formación. Los resultados arrojan diferencias estadísticamente significativas en autorregulación del aprendizaje para el alumnado participante.
\end{abstract}

Palabras clave: Tutoría entre iguales. Autorregulación del aprendizaje. Motivación. Estrategias de aprendizaje. Educación superior. Práctica basada en evidencia.

\section{Introduction}

The process of European convergence in higher education, in its efforts to improve the quality of teaching-learning processes and their results, has made a strong commitment to a learning-centered model, oriented towards development and acquisition of competencies (Arco \& Fernández, 2011). In this context, students are forced to face their learning in an autonomous, intentional, and effective way, with a great dose of commitment and involvement (Arco \& Fernández, 2011; Fernández et al., 2013; Panadero \& Alonso, 2014). However, some studies suggest that the students' preparation to face this demand is not adequate enough, as they present important deficiencies in several aspects related to the use of learning strategies and the control of certain variables involved in learning (Carbonero et al., 2013; Roces \& Sierra, 2017; Rosário et al., 2015), besides, we cannot forget there aren't many teachers spending time on their students' autonomous learning training (Fernández et al., 2013).

In this sense, there is a clear need for university institutions to implement initiatives and measures aimed at improving the processes and quality of their students' learning (Arco \& Fernández, 2011; Arco et al., 2020; Carbonero et al., 2013; Cerezo et al., 2015; Fernández et al., 2013; Roces \& Sierra, 2017), and to that end, it is essential to consider re-

* Correspondence address [Dirección para correspondencia]:

Francisco Fernández-Martín, Department of Developmental and Educational Psychology, University of Granada, Campus Universitario de Cartuja s/n, 18071 Granada, Spain. E-mail: fdfernan@ugr.es

(Article received: 10-6-2021, revised: 14-7-2021, accepted: 28-7-2021)
Abstract: The aim of this study was to check the impact of an intervention program based on peer-tutoring on self-regulated learning of freshmen, as well as on peer tutors. The sample consisted of 102 freshmen (51 experimental group y 51 control group) and 50 seniors from four different university degrees. Self-regulated learning was measured by the Motivated Strategies Learning Questionnaire. After assigning freshmen randomly to either the experimental or control condition, the study adopted a quasiexperimental research design with a non-equivalent control group controlled by statistical techniques, the intervention consisted of 20 individual tutoring sessions highly structured to freshmen delivered by seniors or tutors, after receiving three sessions of training on tutoring. The results yield statistically significant differences in self-regulated learning on participants.

Keywords: Peer-tutoring. Self-regulated learning. Motivation. Learning strategies. Higher education. Evidence-based practice.

search on the self-regulated learning, given its significant explanatory potential for the key processes involved in learning and academic success (Bernardo et al., 2016; García \& Pérez, 2011; Jansen et al., 2019; Richardson et al., 2012; Rosário et al., 2014; Schneider \& Preckel, 2017; Sitzmann \& Ely, 2011). This construct includes a number of theoretical models that, despite their differences, allow it to be conceived as an active process in which the student, through different strategies, controls, monitors and regulates the cognitive, metacognitive, affective-emotional, motivational, contextual and behavioral variables involved in learning, primarily in order to achieve the established objectives that guide their learning (Hernández \& Camargo, 2017; Jansen et al., 2019; Panadero, 2017; Panadero \& Alonso, 2014; Rosário et al., 2014).

These self-regulated learning processes and strategies can be optimized with certain intervention programs, which in turn promote improvements in learning and performance (Fernández et al., 2013; Jansen et al., 2019; Núñez et al., 2011; Zimmerman, 2015), which has led some universities to offer this type of training to their students (Roces \& Sierra, 2017), using a variety of strategies, resources and materials (e.g., from minimal adjustments to classroom processes, using rubrics, charts, protocols, etc., to specific courses or subjects, face-to-face or virtual) (Hernández \& Camargo, 2017). Nevertheless, a high percentage of these programs do not usually establish any type of evaluation and too often adopt qualitative, pre-experimental or quasi-experimental designs with nonequivalent control groups (Broadbent \& Poon, 2015; Cerezo et al., 2010; Hernández \& Camargo, 2017), which forces us to question the strength of the available evi- 
dence on the efficacy and effectiveness of many of them.

The Peer-Tutoring Program (PTP), in its version 2.0 presented in this research was implemented in the $2017 / 2018$ academic year and incorporates a series of elements that aim to correct these limitations, such as improving the degree of experimentation of these interventions, the fidelity of their implementation and impact. PTP is peer-learning based (i.e., peers of different age and academic year with high levels of self-regulated learning, after a training process, provide help and support with a fixed role in pairs to other students to improve their self-regulated learning) and has been implemented in a previous edition, in which it has already demonstrated its capacity to improve the work and study habits of the participating students, as shown by the results of its evaluation (Arco \& Fernández, 2011). However, these results also showed the need to implement changes in certain elements and characteristics of its design, implementation, and evaluation (e.g., extension of sessions throughout the academic year, increase in monitoring activities, increase in the number of control variables, etc.) (Arco \& Fernández, 2011), modifications that have been included in this version 2.0.

Thus, the purpose of this research was to test the effectiveness of PTP 2.0 in improving self-regulated learning among freshmen, identifying in parallel the effects of participation in the program on tutor students' self-regulated learning. The hypotheses that were established were: (1) as a result of participation in the program, there will be a statistically significant improvement in the self-regulated learning of freshmen in the experimental group compared to students in the control group in the post-test phase; (2) as a consequence of their participation in PTP 2.0, there will be a statistically significant improvement in freshmen' self-regulated learning in the experimental group in the post-test phase with respect to the pre-test phase; and (3) in the case of tutor students, as a result of the program, a statistically significant improvement in self-regulated learning will be observed in the post-test phase with respect to the pre-test phase.

\section{Method}

\section{Participants}

The sample had a total of 152 students from the University of Granada, 102 freshmen and 50 seniors.

Freshmen was divided into two groups: (a) experimental group, composed of 51 students, 43 females and 8 males, with an average age of 18 years old $(S D=0.00)$, and a distribution by degrees of 16 students from the Degree in Pharmacy, 4 from the Degree in Economics, 24 from the Degree in Psychology and 7 from the Degree in Business Administration and Management.; and (b) control group, consisting of 51 students, with the same distribution by degree and sex, and identical mean and age range as the experimental group.

The average age of the student tutors was 22.62 years, with a range between 20 and 32 years. The distribution by degree was 16 students from the Degree in Pharmacy, 4 from the Degree in Economics, 23 from the Degree in Psychology and 7 from the Degree in Administration. By sex, 41 were women and 9 were men, of Spanish nationality.

The sampling was non-probabilistic, of convenience, and implied the following actions: (a) selection of participating degrees, considering the declared interest of their institutional heads, together with the authorization of the ethics committee (150/CEIH/2016), as well as the objectives and resources of the program.; (b) execution of the dissemination plan among the students, i.e., 32 group sessions were held in their respective groups-classrooms during the first 10 minutes of the large group theory class, in which they were verbally informed of the conditions and benefits of the program, in addition to requesting their participation and summoning them to a group recruitment session to formalize their enrollment in the program; (c) implementation of the recruitment plan, i.e., 2 group sessions in the aula magna of each of the participating university centers, in the mornings and afternoons, in which, after providing more information to the students attending and resolving their doubts and queries, 269 freshmen and 141 seniors voluntarily enrolled in the program, for which they had to sign the Participation agreements (document with rights and duties of participants), complete the Participation protocols (self-report with demographic, academic and interest information of participants) (Arco \& Fernández, 2011) and the Motivated Strategies for Learning Questionnaire (MSLQ) (Albert, 2017; García \& Pérez, 2011; Roces et al., 1995), and provide a copy of their academic report; and (d) final selection of the sample.

In this regard, from the 269 freshmen, 83 associated pairs $(N=166)$ were created based on two groups of control variables (Ato et al., 2013) associated with the processes and quality of learning (Barbera et al., 2017; Bernardo et al., 2016; Garcia \& Perez, 2011; Richardson et al., 2012; Schneider \& Preckel, 2017): (a) academic: degree, year, group, subjects and number of credits enrolled, baccalaureate branch of origin, number of times the student has taken the university entrance exam, place of choice of degree in pre-enrolment, average high school grade, average university entrance exam grade, previous dropout and change of studies, repetition of previous courses, self-regulated learning, and effort/commitment; and (b) sociodemographic data: age, sex, marital status, nationality, employment status, with whom they live, socioeconomic status and financing of studies.

The remaining 103 freshmen were excluded due to not having an appropriate associated pair. In addition, the minimum size of incoming freshmen required for program evaluation, total $(N=102)$ and per group $(N=51)$, was calculated, so 32 of the 83 associated pairs were randomly discarded.

On the other hand, from the 141 final year students enrolled in the program, the tutor students were selected $(N=$ 50), considering the following criteria: having an average grade higher than 7 points, presenting a centile score higher than 30 points in the subscales of the MSLQ, and having a score higher than 30 points in the MSLQ subscales (Albert, 
2017; García \& Pérez, 2011; Roces et al., 1995), to have time available in the required time windows, to attend the three training sessions and to pass the different practical exercises carried out during the training.

\section{Instruments}

MSLQ (Albert, 2017; García \& Pérez, 2011; Roces et al., 1995). Like the original version (Pintrich et al., 1993), it is a Likert scale consisting of 81 items with 7 response alternatives (i.e., 1: does not describe me at all, up to 7: describes me completely) grouped into 15 subscales and 5 components: (a) cognitive and metacognitive strategies: rehearsal, elaboration, organization, critical thinking, and metacognitive self-regulation (e.g., "64. When I read subject content, I try to relate new content to the knowledge I already possessed"); (b) resource regulation strategies: time and environment management, effort management, peer learning and help-seeking (e.g., "68. When I do not understand some subject content, I ask a classmate for help"); (c) affective motivation: anxiety (e.g., " 8 . When I am taking a test, I think of those test questions that I cannot answer"); (d) motivation expectations: self-efficacy and control beliefs about learning (e.g., "29. I am convinced that I can master the skills and techniques taught in the subjects"); and (e) value motivation: intrinsic and extrinsic goal orientation, and task value (e.g., "24. When I have the opportunity, I choose jobs that I can learn from, even if they do not guarantee me a good grade"). This instrument was chosen because it is the most widely used to measure self-regulated learning in university students (Roth et al., 2016), in addition to presenting adequate reliability (Cronbach's alpha of .82 and .89 for the motivation and learning strategies components, respectively, and between .48 and .86 points for the subscales) and validity (factor analysis demonstrating its factorial structure).

\section{Procedure}

The methodological design adopted for hypotheses 1 and 2 was quasi-experimental with non-equivalent control group enhanced with statistical control techniques, while for hypothesis 3 it was pre-experimental pre-test-post-test (Ato et al., 2013).

As for the procedure, once the sampling was performed, the freshmen experimental and control groups were configured, i.e., each of the members of the 51 selected associated pairs was randomly assigned to the experimental or control condition. (https://www.randomizer.org). It was then confirmed that the two groups were equivalent with respect to the control variables, given that: (a) some of them had only one value, such as age (18 years old), grade (first year), number of times he/she had taken the university entrance exam (1 time), nationality (Spanish), previous dropout and change of studies ( 0 times), previous repetition of courses ( 0 times), marital status (single) and employment status (not working); (b) other showed the same proportion in both groups, such as degree (Degree in Pharmacy $=31.38 \%$, Degree in Economics $=7.84 \%$, Degree in Psychology $=47.06 \%$, Degree in Business Administration and Management $=13.72 \%$ ), group (morning $=78.40 \%$, afternoon $=21.60 \%$ ), place of choice of degree in pre-registration (first $=90.20 \%$, second $=$ $5.90 \%$, third $=3.90 \%$ ), baccalaureate branch of origin (sciences $=45.10 \%$, humanities and social sciences $=54.90 \%$ ) and sex $($ male $=15.70 \%$, female $=84.30 \%)$; and $(\mathrm{c})$ the nonparametric contrasts carried out revealed no statistically significant differences between the two groups in number of credits enrolled $(U=1300.50, p>.05, d=0.00)$, average high school grade $(U=955.50, p>.05, d=0.02)$, average university entrance exam grade $(U=445.00, p>.05, d=0$. $03)$, average university entrance score $(U=1292.00, p>.05$, $d=0.01$ ), self-regulated learning (see Table 1), effort/engagement $(U=1116.50, p>.05, d=0.01)$, with whom he/she lives $\left(\chi^{2}=0.21, p>.05\right)$, socioeconomic status $\left(\chi^{2}=2.06, p>.05\right)$ and study financing $\left(\chi^{2}=0.04, p>\right.$ $.05)$.

In the terms mentioned above, the student tutors had to undergo training aimed at acquiring the necessary skills to perform their functions in the program effectively and efficiently. To that end, during three three-hour sessions, through an active and participatory methodology (i.e., expository teaching, direct instruction and problem-based learning), the following contents were worked on: (a) session 1: presentation of participants and training plan, program rationale, self-regulated learning model and intervention measures (Arco et al., 2009); (b) session 2: use of the Workbooks (a set of materials in which each of the tutoring sessions was presented in a structured way) (Arco et al., 2009; Fernández \& Arco, 2009a, 2009b), and execution of tasks of the first tutoring session; and (c) session 3: needs assessment of freshmen (preparation and analysis of self-registration), establishment of objectives, strategies and tasks (Arco et al., 2009; Fernández \& Arco, 2009a, 2009b), and analysis and solution of possible difficulties during the tutoring sessions.

Subsequently, we proceeded to the pairing, as recommended by the specialized literature (i.e., Durán, 2002; Fernández, 2007; Tindall \& Black, 2009; Topping, 2015; Topping et al., 2017), assigning to the student tutors, based on their equivalence in degree and time availability, the number of students in the experimental group that requested tutoring (one student tutor requested two students and the rest one student), to then implement the tutoring sessions.

The tutoring sessions were implemented in a fixed-role format of a couple of different ages and academic year, extending throughout the academic year, with a weekly frequency and a duration of 90 minutes. In conclusion, for each student in the assigned experimental group, the student tutors carried out 20 tutoring sessions at the times (i.e., between 9-13h. and 16-20h.) and places (i.e., library work and study rooms and student delegation meeting rooms) arranged in each of the participating university centers. These sessions were structured and sequenced in the Workbooks (Arco et al., 2009; Fernández \& Arco, 2009a, 2009b) to facil- 
itate the work of the student tutors, although they had to adapt and specify certain actions to the characteristics, needs and progress of their students, thus awarding them a greater protagonist and level of responsibility and control in the course of these sessions, as recommended by the literature (Topping, 2015; Topping et al., 2017).

In this sense, in order to work on dispositional and supportive learning strategies, the tutor students and their corresponding freshmen carried out the following actions in session 1: (a) presentation and guided tour of the Faculty, describing its services and providing relevant academic information; (b) recording in Workbooks contact information, schedules and locations of sessions, academic information (subjects, professors and tutorials) and relevant dates (e.g., exams, assignments, etc.); (c) reading and comments on their rights and duties; (d) description of university services; (e) completion of a brief description of what was learned in this session; and (f) assignment of tasks to the freshmen for the following session (preparation of self-registration). In tutoring session 2, regarding the metacognitive strategies of planning and regulation, the student tutors and their freshmen jointly carried out the following actions: review of pending tasks, exploration of the self-regulated learning model included in the Workbooks, needs assessment of the freshmen (analysis of self-registration, as well as the selection, recording and graphic representation of relevant variables: hours of sleep, hours of study that hurts and does not hurt, and hours of leisure), establishment of objectives, strategies and tasks related to the environmental conditions of study and time planning (analysis and changes in study conditions, analysis of academic tasks, elaboration of weekly study plan and establishment of rewards, taking as a reference the information provided in the Workbooks), a brief description of what has been learned and a list of the tasks for the next session (implementation of the study plan and recording of the degree of compliance). On the other hand, the aspects worked on by the student tutors and their freshmen on metacognitive strategies of planning, regulation and evaluation in session 3 were: review of set tasks, comparative analysis between the weekly study plan prepared and its degree of compliance, with recording and graphic representation of variables, establishment of objectives, strategies and tasks associated with time planning and procrastination (making adjustments to the study plan and self-administration of rewards, based on the information provided in the Workbooks), brief description of what was learned in this session and assignment of tasks for the next session (implementation of the study plan, with the adjustments made, and recording of its degree of compliance).

Regarding the rest of the sessions, the structure and sequence of action was common to session 3, and was aimed at perfecting and reinforcing the freshmen' study plan and their degree of compliance (metacognitive strategies for planning, regulation and evaluation), but also establishing parallel objectives, strategies and tasks related to healthy habits (sleep hygiene in session 4 and nutrition in session 5), cognitive strategies for rehearsal, organization and elaboration (techniques for searching, collecting and selecting information in sessions 6 and 12, repetition techniques in session 7 , and techniques for establishing relationships when working with information in sessions 13,14 and 15), and dispositional and support strategies (reduction of public speaking anxiety in sessions 16 and 17), always taking as a reference the information provided in the Workbook. However, the three sessions prior to the exam periods (sessions 8 , 9 and 10, and 18,19 and 20) were characterized by a work aimed at the freshmen: (a) to examine and reinforce their study plan, respecting class time, meals and sleep; (b) to increase review, providing more time to consolidate (understanding and memorizing) knowledge, and simulated evaluation; (c) to control their anxiety before exams; and (d) to make coherent and realistic decisions when prioritizing subjects. In addition, the first session of the second semester (session 11), was devoted to the joint assessment of the results achieved in the first semester, specifying attributions, in order to establish objectives, strategies and tasks related to metacognitive strategies of planning and regulation (analysis of tasks on new subjects and study plan), also stimulating positive attitudes towards new teachers and subjects.

In addition, in parallel to the intervention plan, a monitoring plan was developed to monitor possible deviations from the program: (a) a passive participant observer was included in the training with the tutoring students; (b) 3 individual monitoring sessions between those responsible for the program and the tutoring students after tutoring sessions 2 , 5 and 15, in which the actions carried out in these tutoring sessions were evaluated and the appropriate recommendations were issued with a view to establishing objectives, strategies and tasks in the following sessions; and (c) 2 monitoring group sessions after tutoring sessions 10 and 20, in which the program, the difficulties in its development and possible solutions were globally assessed. Finally, with the outcome evaluation plan, measures were taken of the dependent variable, before and after the implementation of the program, to verify the presence or absence of statistically and educationally significant effects.

\section{Data analysis}

Power and sample size analyses were calculated considering the expected effect size (0.50), the associated probability (.05) and the desired statistical power levels (0.80) (Soper, 2021).

Likewise, after checking the absence of univariate (Kolmogorov-Smirnov and Shapiro-Wilk tests) and multivariate (Mardia coefficients) normality in the distribution of the scores, and the absence of outliers, missing and influential values (Mahalanobis distance), the data were analyzed using the tests: (a) Mann-Whitney $U$ test for two independent samples and Pearson $\chi^{2}$ to determine the equivalence of the experimental and control groups in the control variables; (b) Mann-Whitney $U$ test for two independent samples for hy- 
pothesis 1; and (c) Wilcoxon $z$ test for hypotheses 2 and 3. In addition, Cohen's $d$ value was calculated, while the error rate per family, resulting from the problem of multiple comparisons, given the impossibility of performing multivariate contrasts, was controlled with the Bonferroni correction.

\section{Results}

The significance level for each of the multiple comparison tests was adjusted with the Bonferroni correction, being .003 for the different hypotheses (.05/15).

The results derived from the intergroup comparisons in the pre-test phase reveal no statistically significant differences in self-regulated learning, while in the post-test phase, hypothesis 1, statistically significant differences in favor of the experimental group were observed in self-efficacy, control beliefs about learning, metacognitive self-regulation, and time and environment management (Table 1).

Table 1

Intergroup comparisons on self-regulated learning of freshmen.

\begin{tabular}{|c|c|c|c|c|c|c|c|c|c|c|c|}
\hline \multirow[t]{2}{*}{ Subscale / Group } & \multirow{2}{*}{$N$} & \multicolumn{5}{|c|}{ Pre-test } & \multicolumn{5}{|c|}{ Post-test } \\
\hline & & $M$ & $D T$ & $U$ & $p$ & $d$ & $M$ & $D T$ & $U$ & $p$ & $d$ \\
\hline \multicolumn{12}{|l|}{ Intrinsic goal orientation } \\
\hline Experimental & 51 & 4.90 & 0.88 & \multirow{2}{*}{1179.00} & \multirow{2}{*}{.42} & \multirow{2}{*}{0.04} & 5.07 & 0.89 & \multirow{2}{*}{431.50} & \multirow{2}{*}{.10} & \multirow{2}{*}{0.45} \\
\hline Control & 51 & 4.94 & 0.96 & & & & 4.64 & 1.02 & & & \\
\hline \multicolumn{12}{|l|}{ Extrinsic goal orientation } \\
\hline Experimental & 51 & 5.21 & 1.13 & \multirow{2}{*}{1233.50} & \multirow{2}{*}{.78} & \multirow{2}{*}{0.09} & 5.29 & 1.02 & \multirow{2}{*}{509.00} & \multirow{2}{*}{.65} & \multirow{2}{*}{0.20} \\
\hline Control & 51 & 5.31 & 1.12 & & & & 5.05 & 1.35 & & & \\
\hline \multicolumn{12}{|l|}{ Task value } \\
\hline Experimental & 51 & 5.64 & 0.59 & \multirow{2}{*}{1280.00} & & & 5.38 & 0.87 & & & \\
\hline Control & 51 & 5.56 & 0.79 & & .89 & 0.11 & 5.27 & 0.80 & 486.00 & .35 & 0.13 \\
\hline Self-efficacy & & & & & & & & & & & \\
\hline Experimental & 51 & 5.00 & 0.77 & & & & 5.78 & 0.49 & 8550 & & \\
\hline Control & 51 & 4.90 & 0.73 & 1279.50 & .89 & 0.15 & 4.33 & 1.00 & 85.50 & .00 & 1.84 \\
\hline Control beliefs about le & & & & & & & & & & & \\
\hline Experimental & 51 & 4.99 & 0.97 & & & & 5.62 & 0.82 & 19800 & $00^{*}$ & 130 \\
\hline Control & 51 & 4.85 & 0.92 & 1058.50 & .11 & 0.14 & 4.54 & 0.84 & 198.00 & .00 & 1.50 \\
\hline Anxiety & & & & & & & & & & & \\
\hline Experimental & 51 & 3.85 & 1.51 & 128150 & 90 & 002 & 3.78 & 1.35 & 45500 & 34 & 027 \\
\hline Control & 51 & 3.82 & 1.39 & 1281.50 & (90 .90 & 0.02 & 4.18 & 1.63 & 453.00 & .04 & 0.21 \\
\hline Rehearsal & & & & & & & & & & & \\
\hline Experimental & 51 & 5.03 & 1.20 & 125550 & 89 & 0.08 & 5.30 & 1.01 & 516.50 & 57 & 012 \\
\hline Control & 51 & 5.12 & 0.97 & 1253.50 & (0) & 0.00 & 5.18 & 1.03 & 510.30 & (3) & 0.12 \\
\hline Elaboration & & & & & & & & & & & \\
\hline Experimental & 51 & 5.14 & 1.02 & 113900 & 28 & 0.12 & 5.33 & 0.92 & 495,50 & 67 & 0.02 \\
\hline Control & 51 & 5.26 & 0.97 & $115 \% .00$ & .20 & & 5.31 & 0.82 & 495.50 & .07 & 0.02 \\
\hline Organization & & & & & & & & & & & \\
\hline Experimental & 51 & 4.62 & 1.37 & 1036.00 & 18 & 0.13 & 5.01 & 1.07 & 537.50 & 93 & 0.00 \\
\hline Control & 51 & 4.79 & 1.27 & 1050.00 & .18 & 0.15 & 5.01 & 1.39 & $53 / .50$ & 93 & 0.00 \\
\hline Critical thinking & & & & & & & & & & & \\
\hline Experimental & 51 & 4.17 & 1.31 & & & & 4.76 & 1.25 & & & 0.57 \\
\hline Control & 51 & 4.29 & 1.25 & 1243.00 & .70 & 0.09 & 4.06 & 1.19 & 386.50 & .03 & $0.5 /$ \\
\hline Metacognitive self-regulation & & & & & & & & & & & \\
\hline Experimental & 51 & 4.78 & 0.80 & & & & 5.16 & 0.70 & & $00^{*}$ & 0.81 \\
\hline Control & 51 & 4.61 & 0.83 & 1110.50 & .45 & 0.21 & 4.62 & 0.63 & 202.00 & .00 & 0.81 \\
\hline Time and environment man & & & & & & & & & & & \\
\hline Experimental & 51 & 4.78 & 0.52 & 1064.00 & .20 & 0.04 & 5.29 & 0.65 & 268.00 & $.00^{*}$ & 0.98 \\
\hline Control & 51 & 4.76 & 0.40 & 1004.00 & .20 & 0.04 & 4.71 & 0.52 & 200.00 & .00 & 0.90 \\
\hline Effort management & & & & & & & & & & & \\
\hline Experimental & 51 & 3.94 & 0.76 & 1233.00 & 65 & 0.12 & 4.19 & 0.70 & 509.50 & 51 & 0.20 \\
\hline Control & 51 & 4.03 & 0.74 & 1203.00 & (.0 & 0.12 & 4.04 & 0.77 & 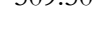 & .01 & 0.20 \\
\hline Peer learning & & & & & & & & & & & \\
\hline Experimental & 51 & 3.83 & 1.33 & 115800 & 42 & 009 & 4.57 & 1.15 & 36600 & 02 & 0.57 \\
\hline Control & 51 & 3.71 & 1.37 & 1158.00 & .42 & 0.09 & 3.87 & 1.31 & 500.00 & .02 & 0.51 \\
\hline Help-seeking & & & & & & & & & & & \\
\hline Experimental & 51 & 4.65 & 0.94 & 998.00 & 60 & 0.05 & 5.03 & 0.90 & 51000 & 52 & 0.06 \\
\hline Control & 51 & 4.70 & 0.96 & 990.00 & .00 & 0.05 & 4.98 & 0.79 & & .52 & 0.00 \\
\hline
\end{tabular}

Note. $M=$ mean; $D T=$ standard deviation; $U=$ Mann-Whitney test for two independent samples; $d=$ effect size (Cohen's $d$ value); $p=$ p-value; ${ }^{*} p<.003$ 
Regarding hypothesis 2, pre-test-post-test comparisons in the experimental group show a statistically significant increase in the post-test phase with respect to the pre-test phase in self-efficacy, control beliefs about learning, metacognitive self-regulation, time and environment management, peer learning, and help-seeking (Table 2). These same comparisons in the control group only show statistically sig- nificant differences in favor of the pre-test phase in selfefficacy (Table 2).

Finally, the results of the intragroup comparisons in the tutor students, hypothesis 3, reveal statistically significant differences in favor of the post-test phase in task value, metacognitive self-regulation, time and environment management, and effort management (Table 3).

Table 2

Intragroup comparisons on self-regulated learning of freshmen.

\begin{tabular}{|c|c|c|c|c|c|c|c|c|c|c|c|}
\hline \multirow[t]{2}{*}{ Subscale / Phase } & \multirow{2}{*}{$N$} & \multicolumn{5}{|c|}{ Control group } & \multicolumn{5}{|c|}{ Experimental group } \\
\hline & & $M$ & $D T$ & $z$ & $p$ & $d$ & $M$ & $D T$ & $z$ & $p$ & $d$ \\
\hline \multicolumn{12}{|c|}{ Intrinsic goal orientation } \\
\hline Pre-test & 51 & 4.94 & 0.96 & \multirow{2}{*}{-1.49} & \multirow{2}{*}{.14} & \multirow{2}{*}{0.30} & 4.90 & 0.88 & \multirow{2}{*}{-0.56} & \multirow{2}{*}{.57} & \multirow{2}{*}{0.19} \\
\hline Post-test & 51 & 4.64 & 1.02 & & & & 5.07 & 0.89 & & & \\
\hline \multicolumn{12}{|c|}{ Extrinsic goal orientation } \\
\hline Pre-test & 51 & 5.31 & 1.12 & \multirow{2}{*}{-1.34} & \multirow{2}{*}{.18} & \multirow{2}{*}{0.21} & 5.21 & 1.13 & \multirow{2}{*}{-0.47} & \multirow{2}{*}{.64} & \multirow{2}{*}{0.07} \\
\hline Post-test & 51 & 5.05 & 1.35 & & & & 5.29 & 1.02 & & & \\
\hline \multicolumn{12}{|l|}{ Task value } \\
\hline Pre-test & 51 & 5.64 & 0.59 & \multirow{2}{*}{-1.45} & & & 5.64 & 0.59 & & & \\
\hline Post-test & 51 & 5.56 & 0.79 & & .15 & 0.11 & 5.38 & 0.87 & -1.51 & .13 & 0.35 \\
\hline Self-efficacy & & & & & & & & & & & \\
\hline Pre-test & 51 & 4.90 & 0.73 & -457 & $00^{*}$ & 065 & 5.00 & 0.77 & -430 & $00^{*}$ & 121 \\
\hline Post-test & 51 & 4.33 & 1.00 & -4.57 & .00 & 0.05 & 5.78 & 0.49 & -4.39 & .00 & 1.21 \\
\hline Control beliefs about & & & & & & & & & & & \\
\hline Pre-test & 51 & 4.85 & 0.92 & - 200 & 03 & 035 & 4.99 & 0.97 & -428 & $00^{*}$ & 070 \\
\hline Post-test & 51 & 4.54 & 0.84 & -2.20 & .03 & 0.55 & 5.62 & 0.82 & -4.28 & .00 & $0 . / 0$ \\
\hline Anxiety & & & & & & & & & & & \\
\hline Pre-test & 51 & 3.82 & 1.39 & 241 & 02 & 024 & 3.85 & 1.51 & 067 & 50 & 005 \\
\hline Post-test & 51 & 4.18 & 1.63 & -2.41 & .02 & 0.24 & 3.78 & 1.35 & $-0.0 /$ & .50 & 0.05 \\
\hline Rehearsal & & & & & & & & & & & \\
\hline Pretest & 51 & 5.12 & 0.97 & ( 38 & 70 & 006 & 5.03 & 1.20 & 131 & 10 & 024 \\
\hline Postest & 51 & 5.18 & 1.03 & -0.50 & .10 & 0.00 & 5.30 & 1.01 & -1.51 & .19 & 0.24 \\
\hline Elaboration & & & & & & & & & & & \\
\hline Pre-test & 51 & 5.26 & 0.97 & ( 30 & 77 & 005 & 5.14 & 1.02 & 040 & 63 & 020 \\
\hline Post-test & 51 & 5.31 & 0.82 & -0.30 & .11 & 0.05 & 5.33 & 0.92 & -0.49 & .03 & 0.20 \\
\hline Organization & & & & & & & & & & & \\
\hline Pre-test & 51 & 4.79 & 1.27 & 023 & 62 & 016 & 4.62 & 1.37 & 180 & 07 & 032 \\
\hline Post-test & 51 & 5.01 & 1.39 & -0.23 & .02 & 0.10 & 5.01 & 1.07 & -1.80 & .01 & 0.52 \\
\hline Critical thinking & & & & & & & & & & & \\
\hline Pre-test & 51 & 4.29 & 1.25 & 108 & 28 & 010 & 4.17 & 1.31 & 205 & $0 ?$ & 046 \\
\hline Post-test & 51 & 4.06 & 1.19 & -1.08 & .28 & 0.19 & 4.76 & 1.25 & -2.23 & .02 & 0.40 \\
\hline Metacognitive self-regu & & & & & & & & & & & \\
\hline Pre-test & 51 & 4.61 & 0.83 & 010 & 02 & 001 & 4.78 & 0.80 & 265 & $00^{*}$ & 0,51 \\
\hline Post-test & 51 & 4.62 & 0.63 & -0.10 & .92 & 0.01 & 5.16 & 0.70 & -2.05 & .00 & 0.51 \\
\hline Time and environment & & & & & & & & & & & \\
\hline Pre-test & 51 & 4.76 & 0.40 & -012 & 00 & & 4.78 & 0.52 & 271 & & \\
\hline Post-test & 51 & 4.71 & 0.52 & -0.12 & .90 & 0.11 & 5.29 & 0.65 & $-2 . / 1$ & .00 & $0.8 /$ \\
\hline Effort management & & & & & & & & & & & \\
\hline Pre-test & 51 & 4.03 & 0.74 & -023 & 82 & 0.01 & 3.94 & 0.76 & -147 & 14 & 0.34 \\
\hline Post-test & 51 & 4.04 & 0.77 & & & & 4.19 & 0.70 & & & \\
\hline Peer learning & & & & & & & & & & & \\
\hline Pre-test & 51 & 3.71 & 1.37 & -070 & 48 & 0.12 & 3.83 & 1.33 & -300 & $00^{*}$ & 060 \\
\hline Post-test & 51 & 3.87 & 1.31 & -0.10 & .40 & 0.12 & 4.57 & 1.15 & -5.00 & .00 & 0.00 \\
\hline Help-seeking & & & & & & & & & & & \\
\hline Pre-test & 51 & 4.70 & 0.96 & - 034 & 73 & ( 32 & 4.65 & 0.94 & -408 & $00^{*}$ & 041 \\
\hline Post-test & 51 & 4.98 & 0.79 & -0.34 & .13 & 0.32 & 5.03 & 0.90 & -4.08 & .00 & 0.41 \\
\hline
\end{tabular}

Note. $M=$ mean; $D T=$ standard deviation; $z=$ Wilcoxon test; $d=$ effect size (Cohen's $d$ value); $p=$ p-value; ${ }^{*} p<.003$ 
Table 3.

\begin{tabular}{|c|c|c|c|c|c|c|}
\hline Subscale / Phase & $N$ & $M$ & $D T$ & z. & $p$ & $d$ \\
\hline \multicolumn{7}{|c|}{ Intrinsic goal orientation } \\
\hline Pre-test & 50 & 5.47 & 0.87 & \multirow{2}{*}{-1.38} & \multirow{2}{*}{.17} & \multirow{2}{*}{0.19} \\
\hline Post-test & 50 & 5.63 & 0.81 & & & \\
\hline \multicolumn{7}{|c|}{ Extrinsic goal orientation } \\
\hline Pre-test & 50 & 5.07 & 1.16 & \multirow{2}{*}{-0.02} & \multirow{2}{*}{.98} & \multirow{2}{*}{0.07} \\
\hline Post-test & 50 & 5.15 & 1.07 & & & \\
\hline \multicolumn{7}{|l|}{ Task value } \\
\hline Pre-test & 50 & 5.84 & 0.64 & \multirow{2}{*}{-3.05} & \multirow{2}{*}{$.00^{*}$} & \multirow{2}{*}{0.59} \\
\hline Post-test & 50 & 6.19 & 0.54 & & & \\
\hline \multicolumn{7}{|l|}{ Self-efficacy } \\
\hline Pre-test & 50 & 5.86 & 0.60 & \multirow{2}{*}{-2.39} & \multirow{2}{*}{.02} & \multirow{2}{*}{0.47} \\
\hline Post-test & 50 & 6.13 & 0.55 & & & \\
\hline \multicolumn{7}{|c|}{ Control beliefs about learning } \\
\hline Pre-test & 50 & 5.24 & 0.86 & \multirow{2}{*}{-0.09} & \multirow{2}{*}{.93} & \multirow{2}{*}{0.02} \\
\hline Post-test & 50 & 5.26 & 0.74 & & & \\
\hline \multicolumn{7}{|l|}{ Anxiety } \\
\hline Pre-test & 50 & 2.77 & 1.11 & \multirow{2}{*}{-2.14} & \multirow{2}{*}{.03} & \\
\hline Post-test & 50 & 2.60 & 1.23 & & & 0.14 \\
\hline Rehearsal & & & & & & \\
\hline Pre-test & 50 & 4.98 & 1.08 & -103 & 30 & 010 \\
\hline Post-test & 50 & 5.18 & 0.99 & -1.03 & .30 & 0.19 \\
\hline Elaboration & & & & & & \\
\hline Pre-test & 50 & 5.67 & 0.76 & -187 & 06 & 025 \\
\hline Post-test & 50 & 5.85 & 0.68 & -1.81 & .00 & 0.25 \\
\hline Organization & & & & & & \\
\hline Pre-test & 50 & 5.81 & 1.14 & -0.63 & 53 & 002 \\
\hline Post-test & 50 & 5.83 & 1.15 & -0.03 & .53 & 0.02 \\
\hline Critical thinking & & & & & & \\
\hline Pre-test & 50 & 4.66 & 0.97 & & & \\
\hline Post-test & 50 & 4.98 & 0.92 & -2.10 & .03 & 0.34 \\
\hline Metacognitive self-re & & & & & & \\
\hline Pre-test & 50 & 5.09 & 0.66 & $-3,42$ & $00^{*}$ & 0.48 \\
\hline Post-test & 50 & 5.37 & 0.48 & -3.42 & .00 & 0.48 \\
\hline Time and environme & & & & & & \\
\hline Pre-test & 50 & 4.71 & 0.41 & & & 0.45 \\
\hline Post-test & 50 & 4.87 & 0.30 & -3.00 & .00 & 0.45 \\
\hline Effort management & & & & & & \\
\hline Pre-test & 50 & 3.73 & 0.58 & & & \\
\hline Post-test & 50 & 4.08 & 0.45 & -3.16 & .00 & $0.0 /$ \\
\hline Peer learning & & & & & & \\
\hline Pre-test & 50 & 4.96 & 1.29 & & & 0.10 \\
\hline Post-test & 50 & 5.09 & 1.27 & -0.14 & .40 & 0.10 \\
\hline Help-seeking & & & & & & \\
\hline Pre-test & 50 & 4.99 & 0.71 & & & \\
\hline Post-test & 50 & 5.11 & 0.72 & -0.54 & .59 & 0.17 \\
\hline
\end{tabular}

\section{Discussion and conclusions}

The purpose of this research was to test the complementary capacity of PTP 2.0 to improve the level of self-regulated learning among university students in comparison with its previous edition. Therefore, considering the results obtained, the following conclusions can be drawn: (1) PTP 2.0 had a statistically significant impact in the post-test phase in favor of the experimental group on certain indicators of selfregulated learning (self-efficacy, control beliefs about learning, metacognitive self-regulation, and time and environment management), so hypothesis 1 can be partially accepted; (2) since statistically significant differences are observed in the experimental group in favor of the post-test phase in certain indicators of self-regulated learning (self-efficacy, control beliefs about learning, metacognitive self-regulation, time and environment management, peer learning, and help-seeking) as a result of the program, hypothesis 2 can also be partially accepted; (3) given that there are statistically significant differences in favor of the post-test phase with respect to the pre-test phase in some indicators of self-regulated learning (task value, metacognitive self-regulation, time and environ- 
ment management, and effort management), hypothesis 3 can also be partially accepted.

These results based on statistical significance, despite the overly conservative nature of the Bonferroni correction, clearly show that participating in PTP 2.0 has a positive and statistically significant effect on various indicators of selfregulated learning. Moreover, if the hypotheses are tested using tests that provide answers on their practical significance, as recommended by the literature (Ledesma et al., 2008), the effect size achieved for most indicators was medium-large (Cohen, 1988), i.e., the intergroup differences generated can be detected by observation (Coe, 2002). Moreover, it is also necessary to highlight the deterioration over time observed in most of the indicators in the case of the control group, without forgetting the improvements seen in the student tutors.

In sum, the results obtained confirm the effectiveness of PTP 2.0 in improving the levels of self-regulated learning, which also reinforces the idea that this competence can be optimized with appropriate training (Roces \& Sierra, 2017). Likewise, PTP 2.0 has demonstrated greater effectiveness than its previous version (Arco \& Fernández, 2011) and even other programs with different strategies, resources, and materials (e.g., learning to learn courses, audiovisual workshops, web applications, rubrics, and letters) (Hernández \& Camargo, 2017; Roces \& Sierra, 2017), although it is also necessary to highlight its greater efficiency. Of course, this increased effectiveness and efficiency of PTP 2.0 can be attributed to the incorporation of peer-tutoring as an intervention strategy, but also to the key changes and improvements revealed by the evaluation of the previous edition.

Nevertheless, when interpreting the results obtained, it is also necessary to consider certain methodological limitations such as, firstly, (a) the possible sample selection bias, which means that the program is only suitable for students who are willing to benefit from this training, (b) the possible measurement bias, by using a single instrument to measure the dependent variable, or (c) the possible grouping effects, which may mean that the results in new students are the result of the level of competence of the tutor students (Arco et al., 2020). Secondly, mention should be made of the absence of statistically significant differences in some indicators of self-regulated learning, as well as the size of the effect achieved, since it was of a small magnitude. However, these values do not jeopardize the importance and contribution of this research, mainly because effect sizes in educational research are usually much smaller than in other disciplines, and values around 0.30 are already considered of important prac-

\section{References}

Albert, A. (2017). Evaluación del aprendizaje autorregulado: validación del Motivated Strategies Learning Questionnaire en Educación Secundaria [Evaluation of self-regulated learning: Validation of the Motivated Strategies Learning Questionnaire in Secondary Education] [Tesis doctoral, Universidad de Valencia]. Roderic, Repositori de Contingut Lliure. http://roderic.uv.es/handle/10550/59163

Arco, J. L., \& Fernández, F. D. (2011). Eficacia de un programa de tutoría entre tical relevance (Hattie, 2009). Thirdly, it should be pointed out that, in this edition of the program, despite the efforts made, it has again been impossible to complement the tasks performed by the student tutors with the tutorial action of the teaching staff. And, fourthly, in similar terms to the previous edition of the program, certain difficulties have been identified linked to the behavior of the participating students (e.g., lack of punctuality, attendance to sessions without materials, etc.).

In this sense, in future work, it would be appropriate to evaluate the program in other university degrees and institutions, and even in previous educational stages, of course, after making the appropriate adjustments and adaptations. Obviously, it is always possible to increase the size and representativeness of the sample, the number of measurement instruments and increase the degree of experimentation of any applied research, as well as to modify those elements and characteristics of the program that continue to be susceptible to improvement, but this type of improvement will always require greater economic resources (Bettinger \& Baker, 2014). It would also be desirable to confirm whether the effects of the program are maintained over time, and even if these effects lead to improvements in the academic performance of students, as this is one of the main criticisms and challenges of these interventions (Arco \& Fernandez, 2011; Roces \& Sierra, 2017).

This research provides empirical evidence on the power and validation of the PTP 2.0 causal model of intervention to generate improvements in the processes and quality of university student learning, in addition to providing higher education institutions with an efficient, very low-cost tool or initiative to do so (Arco et al., 2020). In this sense, and following international standards of quality in educational innovations, it can be stated that this is an example of an evidence-based practice or program (Slavin, 2017). The scarcity of works with these characteristics and methodological rigor (Hernández \& Camargo, 2017) recommends continuing to support the systematic evaluation of this type of interventions, in order to accumulate more evidence and improve their impact.

Acknowledgments.- The authors would like to thank the Ministry of Science and Innovation for funding the previous edition of this program, within the framework of the Project SEJ2007-68099.

Conflict of interest.- The authors declare that there is no conflict of interest.

iguales para la mejora de los hábitos de estudio del alumnado Universitario [Efficacy of a peer tutoring program to improve the study habits of university students]. Revista de Psicodidáctica, 16(1), 162-180.

Arco, J. L., Fernández, F. D., \& Hervás, M. (2020). Evidence-based peer-tutoring program to improve students' performance at the university. Studies in Higher Education, 45(11), 2190- 
2202. http://doi.org/10.1080/03075079.2019.1597038

Arco, J. L., López, S., Fernández, F. D., Jiménez, E., Caballero, R., \& Heilborn, V. A. (2009). Guia psicopedagógica para estudiantes y profesores universitarios en el Espacio Europeo de Educación Superior [Psychopedagogical guide for university students and professors in the European Higher Education Area]. Universidad de Granada.

Ato, M. (2010). Tipología de los diseños cuasiexperimentales [Typology of quasiexperimental designs]. En M. T. Anguera, J. Arnau, M. Ato, R. Martínez, J. Pascual, \& G. Vallejo (Eds.), Métodos de investigación en Psicologia [Research methods in Psychologyl (pp. 245-269). Síntesis.

Ato, M., López, J. J., \& Benavente, A. (2013). Un sistema de clasificación de los diseños de investigación en Psicología [A classification system for research designs in Psychology]. Anales de Psicología, 29(3), 1038-1059. https://doi.org/10.6018/analesps.29.3.178511

Barbera, S. A., Berkshire, S. D., Boronat, C. B., \& Kennedy, M. H. (2017). Review of undergraduate student retention and graduation since 2010: Patterns, predictions, and recommendations for 2020. Journal of College Student Retention: Research, Theory \& Practice, 31, 1-24. https://doi.org/10.1177/1521025117738233

Bernardo, A., Esteban, M., Fernández, E., Cervero, A., Tuero, E. \& Solano, P. (2016). Comparison of personal, social and academic variables related to university drop-out and persistence. Frontiers in Psychology, 7, 1610. https://doi.org/10.3389/fpsyg.2016.01610

Bettinger, E. P., \& Baker B. (2014). The effects of student coaching: An evaluation of a randomized experiment in student advising. Educational Evaluation and Policy Analysis, 36(1), 3-19. https://doi.org/10.3102/0162373713500523

Broadbent, J., \& Poon, W. L. (2015). Self-regulated learning strategies and academic achievement in online higher education learning environments: A systematic review. The Internet and Higher Education, 27, 1-13. https://doi.org/10.1016/i.iheduc.2015.04.007

Carbonero, M. A., Román, J. M., \& Ferrer, M. (2013). Programa para “aprender estratégicamente" con estudiantes universitarios: diseño y validación experimental [Program to "learn strategically" with university students: Design and experimental validation]. Anales de Psicologia, 29(3), 876-885. https://doi.org/10.6018/analesps.29.3.165671

Cerezo, R., Bernardo, A., Esteban, M., Sánchez, M., \& Tuero, E. (2015). Programas para la promoción de la autorregulación en educación superior: un estudio de la satisfacción diferencial entre metodología presencial y virtual [Programs for the promotion of self-regulation in higher education: A study of the differential satisfaction between face-to-face and virtual methodology]. European Journal of Education and Psychology, 8(1), 30-36. https://doi.org/10.1016/i.ejeps.2015.10.004

Cerezo, R., Núñez, J. C., Rosário, P., Valle, A., Rodríguez, S., \& Bernardo, A. B. (2010). New media for the promotion of self-regulated learning in higher education. Psicothema, 22(2), 306-315.

Coe, R. (2002, 12-14 septiembre). It's the effect size, stupid. What effect size is and why it is important. British Educational Research Association Annual Conference, Exeter, https://www.leeds.ac.uk/educol/documents/00002182.htm

Cohen, J. (1988). Statistical power analysis for the behavioral sciences (2 $2^{\mathrm{a}}$ ed.). Lawrence Erlbaum Associates.

Durán, D. (2002). Tutoría entre iguales. Procesos cognitivo-relacionales y análisis de la interactividad en tutorias fjias y reciprocas [Peer tutoring. Cognitive-relational processes and analysis of interactivity in fixed and reciprocal tutorials] [Tesis doctoral no publicada]. Universidad Autónoma de Barcelona.

Fernández, F. D. (2007). La tutoría entre compañeros en la universidad [Peer-tutoring in university] [Tesis doctoral, Universidad de Granada]. Repositorio Institucional de la Universidad de Granada. http://hdl.handle.net/10481/1448

Fernández, F. D., \& Arco, J. L. (2009a). Cuaderno de formación y trabajo del tutor PTEC [PTP tutors workbook]. Universidad de Granada.

Fernández, F. D., \& Arco, J. L. (2009b). Cuaderno de trabajo de alumnos PTEC [PTP student workbook]. Universidad de Granada.

Fernández, E., Bernardo, A., Suárez, N., Cerezo, R., Núñez, J. C., \& Rosario, P. (2013). Predicción del uso de estrategias de autorregulación en educación superior [Predicting the use of self-regulation strategies in higher education: An analysis at the individual and context level]. Anales de Psicologia, 29(3), 865-875. https://doi.org/10.6018/analesps.29.3.139341

García, R., \& Pérez, F. (2011). Validez predictiva e incremental de las habilidades de autorregulación sobre el éxito académico en la Universidad Predictive and incremental validity of self-regulation skills on academic success at university]. Revista de Psicodidáctica, 16(2), 231-250.

Hattie, J. (2009). Visible learning: A synthesis of meta-analyses in education. Routledge

Hernández, A., \& Camargo, A. (2017). Autorregulación del aprendizaje en la educación superior en Iberoamérica: una revisión sistemática [Self-regulated learning in higher education in Latin-America: A systematic review]. Revista Latinoamericana de Psicología, 49 $146-160$. https://doi.org/10.1016/i.rlp.2017.01.001

Jansen, R. S., van Leeuwen, A., Janssen, J., Jak, S., \& Kester, L. (2019). Selfregulated learning partially mediates the effect of self-regulated learning interventions on achievement in higher education: A meta-analysis. Educational Research Review, 28, 100292. https://doi.org/10.1016/i.edurev.2019.100292

Ledesma, R., Macbeth, G., \& Cortada, N. (2008). Tamaño del efecto: revisión teórica y aplicaciones con el sistema estadístico ViSta [Effect size: theoretical review and applications with the ViSta statistical system]. Revista Latinoamericana de Psicologia, 40(3), 425-439.

Núñez, J. C., Cerezo, R., Bernardo, A., Rosário, P., Valle, A., Fernández, E., \& Suárez, N. (2011). Implementation of training programs in self-regulated learning strategies in Moodle format: Results of an experience in higher education. Psicothema, 23(2), 274-281.

Panadero, E. (2017). A review of self-regulated learning: Six models and four directions for research. Frontiers in Psychology, 8(422). https://doi.org/10.3389/fpsyg.2017.00422

Panadero, E., \& Alonso, J., (2014). ¿Cómo autorregulan nuestros alumnos? Revisión del modelo cíclico de Zimmerman sobre autorregulación del aprendizaje [How do students self-regulate? Review of Zimmerman's cyclical model of self-regulated learning]. Anales de Psicologia, 30(2), 450-462. https://doi.org/10.6018/analesps.30.2.167221

Pintrich, P. R., Smith, D., García, T., \& McKeachie, W. (1993). Reliability and predictive validity of the Motivated Strategies for Learning Questionnaire (MSLQ). Educational and Psychological Measurement, 53(3), 801-813. https://doi.org/10.1177/0013164493053003024

Richardson, M., Abraham, C., \& Bond, R. (2012). Psychological correlates of university students' academic performance: A systematic review and metaanalysis. Psychological Bulletin, 138(2), 353-387. https://doi.org/10.1037/a0026838

Roces, C., \& Sierra, B. (2017). The effectiveness of a learning strategies program for university students. Psicothema, 29(4), 527-532. https://doi.org/10.7334/psicothema2016.171

Roces, C., Tourón, J., \& González, M. C. (1995). Validación preliminar del CEAM II [Preliminary validation of CEAM II]. Psicológica, 16, 347-366.

Rosário, P., Nuñez, J. C., Trigo L., Guimarães, C., Fernández, E., Cerezo, R. Fuentes, S., Orellana, M., Santibáñez, A., Fulano, C., Ferreira, A., \& Figueiredo, M. (2015). Transcultural analysis of the effectiveness of a program to promote self-regulated learning in Mozambique, Chile, Portugal, and Spain. Higher Education Research and Development, 34(1), 173-187. https://doi.org/10.1080/07294360.2014.935932

Rosário, P., Pereira, A., Högemann, J., Nunez, A. R., Figueiredo, M., Núñez, J. C., Fuentes, S., \& Gaeta, M. L. (2014). Autorregulación del aprendizaje: una revisión sistemática en revistas de la base SciELO [Self-regulated learning: A systematic review in SciELO-based journals]. Universitas Psychologica, 13(2), 781-798. https://doi.org/10.11144/Javeriana. UPSY13-2.aars

Roth, A., Ogrin, S., \& Schmitz, B. (2016). Assessing self-regulated learning in higher education: A systematic literature review of self-report instruments. Educational Assessment, Evaluation and Accountability, 28(3), 225-250. https://doi.org/10.1007/s11092-015-9229-2

Schneider, M., \& Preckel, F. (2017). Variables associated with achievement in higher education: A systematic review of meta-analyses. Psychological Bulletin 143(6), 565-600. https://doi.org/10.1037/bul0000098

Slavin, R. (2017). Evidence-based reform in education. Journal of Education for Stu$\begin{array}{lllll}\text { dents Placed at Riske, 22(3), 178-184. } & \end{array}$ https://doi.org/10.1080/10824669.2017.1334560

Sitzmann, T., \& Ely, K. (2011). A meta-analysis of self-regulated learning in work-related training and educational attainment: What we know and where we need to go. Psychological Bulletin, 137(3), 421-442. https://doi.org/10.1037/a0022777

Soper, D. S. (2021). A-priori sample size calculator for students t-test [Software]. https://www.danielsoper.com/statcalc/calculator.aspx?id $=47$

Tindall, J. A., \& Black, D. R. (2009). Peer programs: An in-depth look at peer helping. Planning, implementation and administration (2nd ed.). Routledge, Taylor \& Francis Group.

Topping, K. J. (2015). Peer tutoring: Old method, new development. Infancia y Aprendivaje, 38(1). https://doi.org/10.1080/02103702.2014.996407

Topping, K. J., Buchs, C., Duran, D., \& Van Jeer, H. (2017). Effective peer learning. From principles to practical implementation. Routledge, Taylor \& Francis Group.

Zimmerman, B. J. (2015). Self-regulated learning: Theories, measures, and outcomes. En J. D. Wright (Ed.), International Encyclopedia of the Social \& Behavior al Sciences (2a ed., pp. 541-546). Elsevier. https://doi.org/10.1016/B978-0 08-097086-8.26060-1 